\title{
Elemental composition of otoliths as a discriminator of life stage and growth habitat of the European eel, Anguilla anguilla
}

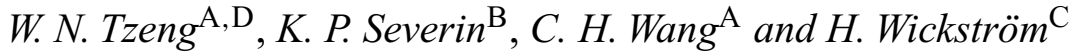 \\ ${ }^{A}$ Institute of Fisheries Science, College of Life Science, National Taiwan University, Taipei 106, Taiwan. \\ ${ }^{B}$ Department of Geology and Geophysics, University of Alaska Fairbanks, Alaska 99775-0760, USA. \\ ${ }^{\mathrm{C}}$ National Board of Fisheries, Institute of Freshwater Research, SE-178 93 Drottningholm, Sweden. \\ DCorresponding author. Email: wnt@ccms.ntu.edu.tw
}

\begin{abstract}
The hypothesis that elemental composition of otoliths of the eel (Anguilla spp.) changes with life stage and growth habitat was tested in the present study. The minor elements $\mathrm{Cl}, \mathrm{Na}, \mathrm{K}, \mathrm{Mg}, \mathrm{Ca}, \mathrm{Sr}$ and $\mathrm{P}$ in otoliths of European eels (Anguilla anguilla) were examined by using an Electron Probe Microanalyser (EPMA) equipped with wavelength dispersive spectrometers (Cameca SX-50). Yellow-stage eels were collected from coastal waters and lakes of Sweden in 1987, 1988, 1991, and 1994, with ages ranging from 5 to 18 years old. Strontium maps and profiles of $\mathrm{Sr}$ : Ca ratio, as well as the elver check in otoliths, were used to classify life history stages of the eels as leptocephalus, and freshwater- and seawater-resident yellow eels. Canonical score plots of the otolith elemental compositions of the freshwater-resident yellow eel were completely separated from those of leptocephalus and seawater-resident yellow eel, but the latter two partially overlapped. Strontium is the primary component in determining the discrimination, but the nutrient-related ( $\mathrm{S}$ and $\mathrm{P}$ ), and the physiologically controlled elements $(\mathrm{Na}$ and $\mathrm{Cl})$, may also play an important role in the discrimination. These results indicate that multiple-elemental information can provide additional insight into the migratory environmental history of diadromous fishes.
\end{abstract}

Extra keywords: electron probe microanalysis, microchemistry.

\section{Introduction}

The European eel, Anguilla anguilla (L.), is a diadromous fish, widely distributed in freshwater and marine littoral areas of North Africa, the Mediterranean Sea, the British Isles, Iceland, and the western and northern European continent (Tesch 2003). After spawning in the Sargasso Sea, the leptocephali are transported by the North Equatorial Current, Gulf Stream and North Atlantic Current to the continental shelf of northern European countries (Bertin 1956). The larvae metamorphose into glass eels in coastal waters. Glass eels become pigmented elvers when they enter estuaries. Their migration from the Sargasso Sea to the estuaries requires 6-9 months (Lecomte-Finiger 1992), or 14-16 months (Wang and Tzeng 2000). Male eels grow in rivers for 3-7 years, whereas female eels grow from 4 to 15 years in rivers (Vollestad and Jonsson 1986). In late autumn, they transform from the yellow eel into silver eel stage and start the downstream migration back to the Sargasso Sea. Recent studies on $\mathrm{Sr}$ (strontium) : Ca (calcium) ratios in otoliths indicate that a part of the eel population may skip the freshwater life of the yellow eel phase and can complete their entire life history in the seawater (Tzeng et al. 1997, 2000; Tsukamoto et al. 1998; Tsukamoto and Arai 2001).
Ratios of $\mathrm{Sr}: \mathrm{Ca}$ in the otolith of anguillid eels dramatically change at metamorphosis from leptocephalus to glass eel during their migration from the ocean to the river (Otake et al. 1994; Tzeng and Tsai 1994; Arai et al. 1997). This drastic change in $\mathrm{Sr} / \mathrm{Ca}$ ratios was proposed to be related to metamorphosis rather than the transition of habitat from seawater to fresh water (Tzeng 1996). In contrast, the $\mathrm{Sr}: \mathrm{Ca}$ ratios in otoliths of yellow eels changed significantly when the eel migrated between fresh water and seawater (Tzeng et al. 1997, 2002, 2003a, 2003b; Jessop et al. 2002, 2004; Kraus and Secor 2003; Limburg et al. 2003; Shiao et al. 2003; Cairns et al. 2004). These indicated that the changes in otolith microchemistry throughout their life history of the eel were more complicated than our current understanding. Therefore, it is important to examine how elemental composition of eel otoliths is influenced by both ontogenetic developments and habitat shift before using the elemental signature to reconstruct their migratory environmental history.

In the present study, elements in addition to $\mathrm{Ca}$ and $\mathrm{Sr}$ were measured to further understand the change in elemental composition of otoliths in European eels during metamorphosis from leptocephalus to glass eel and during migration of yellow-phase eels between fresh water and seawater. 


\section{Materials and methods}

\section{Sampling designs}

Ten otoliths of European eels collected from three freshwater lakes and two brackish estuaries in Sweden were used for microchemical analysis. These samples were classified into four groups according to sampling sites (Tzeng et al. 1997). The origin of groups 1 through 3 was clear: these eels were captured from areas where the restocking programme is well known. The individuals of group 4 were collected from a site some kilometres away from Eastern Lake Mälaren in 1994, and the origin of this group was unknown. They were derived either from a natural population that had migrated from brackish Baltic Sea, or from a stocked population caught from brackish waters on the west coast of Sweden and released at the yellow eel stage at $\sim 40 \mathrm{~cm}$ in total length, or from a stocked population released at the elver stage imported from France or the British Isles. The stocking and sampling dates and biological characteristics of the four groups of eels (including sampling date, mean ( \pm s.d.) salinity of sampling sites, stage, age, total length, bodyweight, and the stage and year at stocking) are given in Table 1.

\section{Microchemical analysis}

After removal from the eel, the otoliths were cleaned with distilled water, dried in air, embedded in thermo-epoxy (Petropoxy 154; Palouse Petro Products, Pullman, WA) and cured for $1 \mathrm{~h}$ at $135^{\circ} \mathrm{C}$. Embedded otoliths were ground from the proximal side of the sagittal plane of the fish until the primordium of the otolith was revealed. For microprobe analysis, the polished otoliths were coated under vacuum with a $30 \mathrm{~nm}$ layer of carbon to increase electron conductance.

The elemental composition of the eel otolith was measured with an electron probe microanalyser (EPMA) equipped with wavelength dispersive X-ray spectrometer (Cameca SX-50, Paris, France). Measurements were made at $\sim 18 \mu \mathrm{m}$ intervals along a transect from the primordium to the edge of the otolith for each of the 10 yellow eels in Table 1. The beam condition of the EPMA used in the measurement of these elements was $15 \mathrm{kV}, 4 \mathrm{nA}$, and a $15 \mu \mathrm{m}$ diameter beam. The EPMA has minimum detection limits of a few hundred ppm (Statham 1981, 1982) and is not sensitive enough to detect trace elements. As a result of the detection limit of EPMA, only calcium and seven minor elements ( $\mathrm{Na}, \mathrm{Mg}, \mathrm{Cl}, \mathrm{P}, \mathrm{S}, \mathrm{K}$ and $\mathrm{Sr}$ ) were selected for analysis. The counting time, standard for calibration, detection limit and analytical error for each of the eight elements are listed in Appendix 1.

\section{Data analysis}

The element: $\mathrm{Ca}$ concentration ratios on each sampling spot of the otoliths were calculated by weight (\%) and grouped by stage and habitat use, which determined the life-history stages of leptocephalus of both freshwater- and seawater-resident yellow eels. Leptocephalus and yellow eel were separated by the elver check on the otolith (Shiao et al. 2003) and yellow eels were further divided into freshwater and seawater residents according to the $\mathrm{Sr}$ concentration on the $\mathrm{Sr}$ map and the $\mathrm{Sr}: \mathrm{Ca}$ ratio profile in their otoliths (Tzeng et al. 1997, 2002, 2003a, 2003b). Freshwater-resident yellow eel referred to the individuals with a $\mathrm{Sr}: \mathrm{Ca}$ ratio less than $4 \times 10^{-3}$ in between the elver check and the otolith edge. Seawater-resident yellow eel had $\mathrm{Sr}$ : $\mathrm{Ca}$ ratios higher than $4 \times 10^{-3}$ indicating that the individuals did not migrate upstream and lived in high salinity seawater during the yellow eel phase. The estuarine-resident yellow eel migrated between fresh water and seawater.

The significant difference of the mean values of the $\mathrm{Ca}$ element concentration ratios among stages of the eel (leptocephalus, freshwaterand seawater-resident yellow eels) were tested by non-parametric Tukeytype multiple comparisons. The significance of the correlation among different $\mathrm{Ca}$ element ratios on each sampling spots was tested for each life history stages by Pearson product-moment correlation coefficient (Zar 1984). The contribution of the elemental composition to the grouping of the above mentioned life history stages was analysed by using stepwise Canonical Discriminant Analysis. The classification success of the life history stages by the elemental composition was calculated with a discriminant function analysis. All the statistics were preformed by using the software SPSS (SPSS Inc., Chicago, IL).

\section{Results}

\section{Otolith elemental composition changed with life history stage and habitat use}

The mean value of the seven elements: $\mathrm{Ca}$ ratios within otoliths of the yellow eel were ranked in descending order by life history stages and habitat use (Table 2). The $\mathrm{Sr}$ : Ca ratios constituted the first ranking in the elemental composition in the leptocephalus stage, but dropped to second rank in those of seawater-resident yellow eel stage and to the sixth rank in freshwater-resident yellow eel stage. On the contrary, $\mathrm{Na}: \mathrm{Ca}$ ratios rose to the first rank in both seawater- and freshwaterresident yellow eels. This indicated that many elements other than $\mathrm{Sr}$ in otoliths of the eel changed with developmental stage and habitat use.

Each of the mean ( \pm s.e.) element: Ca ratios in otoliths were also compared among life history stages and habitat use (Table 2). Tukey's honestly significantly different (HSD) tests indicated that $\mathrm{Sr}: \mathrm{Ca}$ ratios in otoliths of the

Table 1. Life history of the four groups of yellow stage, female European eels used in the present study

\begin{tabular}{lllllcccc}
\hline Group & Specimen no. & Sampling date & Sampling site & $\begin{array}{l}\text { Salinity } \\
\text { (psu) }\end{array}$ & $\begin{array}{c}\text { Age } \\
\text { (years) }\end{array}$ & $\begin{array}{c}\text { Total } \\
\text { length (mm) }\end{array}$ & $\begin{array}{c}\text { Bodyweight } \\
(\mathrm{g})\end{array}$ & $\begin{array}{l}\text { Stage and year } \\
\text { at stocking }\end{array}$ \\
\hline 1 & 11538 & 9 Jul 1987 & Strömstad (West Coast) & $25.54 \pm 3.38$ & $5+$ & 393 & 96 & Natural \\
& 11550 & 9 Jul 1987 & Strömstad (West Coast) & $25.54 \pm 3.38$ & $7+$ & 410 & 90 & Natural \\
& 11906 & 20 Aug 1987 & Björkö (West Coast) & $23.12 \pm 3.71$ & $9+$ & 403 & 96 & Natural \\
2 & 13743 & 31 May 1988 & Eastern Lake Mälaren & Fresh water & $8+$ & 562 & 442 & Elver, 1980 \\
& 18589 & 7 Jun 1991 & Eastern Lake Mälaren & Fresh water & $11+$ & 717 & 566 & Elver, 1980 \\
3 & 18793 & 1 Jul 1991 & Lake Ången & Fresh water & $\geq 14+$ & 760 & 820 & Yellow eel, 1979 \\
& 19315 & 16 Jul 1991 & Lake Ången & Fresh water & $\geq 18+$ & 728 & 668 & Yellow eel, 1979 \\
4 & 25106 & 30 Aug 1994 & Lake Mälaren & Fresh water & $13+$ & 723 & 597 & Unknown origin \\
& 25108 & 30 Aug 1994 & Lake Mälaren & Fresh water & $18+$ & 721 & 535 & Unknown origin \\
& 25110 & 30 Aug 1994 & Lake Mälaren & Fresh water & $14+$ & 680 & 461 & Unknown origin \\
\hline
\end{tabular}


eel were the highest at marine leptocephalus stage $(1.16 \times$ $\left.10^{-2} \pm 5.56 \times 10^{-4}\right)$, followed by seawater-resident yellow eel $\left(4.75 \times 10^{-3} \pm 1.04 \times 10^{-4}\right)$, and it was the lowest in freshwater-resident yellow eels $\left(3.36 \times 10^{-4} \pm 3.32 \times 10^{-5}\right)$ (Table 2). Similarly, the ratios of $\mathrm{K}: \mathrm{Ca}, \mathrm{Cl}: \mathrm{Ca}, \mathrm{P}: \mathrm{Ca}$, and $\mathrm{S}: \mathrm{Ca}$ were higher in the leptocephalus stage compared with the freshwater- and seawater-resident yellow eels (Table 2). The ratios of $\mathrm{Na}: \mathrm{Ca}$ and $\mathrm{Mg}: \mathrm{Ca}$ were higher in leptocephalus than seawater-resident yellow eels. The ratio of $\mathrm{Na}$ : Ca was higher in freshwater than seawater-resident yellow eels (Table 2). These indicated that except for $\mathrm{Sr}: \mathrm{Ca}$ ratios, the other six element: Ca ratios also changed with life history stages and habitat use of the yellow eels.

\section{Stage/habitat use mediated correlation among element: Ca ratios in otoliths}

The correlations matrix of element: Ca ratios in otoliths of the eel were different in different life history stages and habitat use (Table 3 ), for example, $\mathrm{Sr}$ : Ca ratios were positively correlated with $\mathrm{K}: \mathrm{Ca}, \mathrm{Cl}: \mathrm{Ca}$ and $\mathrm{Na}: \mathrm{Ca}$, and negatively with $\mathrm{S}: \mathrm{Ca}$ in seawater-resident yellow eel stage, but positively correlated with $\mathrm{P}: \mathrm{Ca}$ and $\mathrm{S}: \mathrm{Ca}$ in the leptocephalus stage, and only slightly positively correlated with $\mathrm{K}: \mathrm{Ca}$ in freshwater-resident yellow eels. Similarly, the other element: $\mathrm{Ca}$ ratios also have different combinations of cross correlation. This may indicate that uptake of elements was discriminated among different life history stages of the eel.

Table 2. Ranking of the seven otolith elements to calcium concentration ratios by life history stages of the eel Ratios were compared among stages

\begin{tabular}{|c|c|c|c|c|c|c|c|c|c|c|}
\hline \multirow[t]{2}{*}{$\mathrm{Me} / \mathrm{Ca}$} & \multicolumn{3}{|c|}{ Leptocephalus $(n=99)$} & \multicolumn{3}{|c|}{ Seawater-resident Yellow eel $(n=392)$} & \multicolumn{3}{|c|}{ Freshwater-resident Yellow eel $(n=304)$} & \multirow{2}{*}{$\begin{array}{l}\text { Comparison by } \\
\text { Tukey's HSD test }\end{array}$} \\
\hline & Mean & s.e. & Rank & Mean & s.e. & Rank & Mean & s.e. & Rank & \\
\hline $\mathrm{Sr} / \mathrm{Ca}$ & $1.16 \times 10^{-2}$ & $5.56 \times 10^{-4}$ & 1 & $4.75 \times 10^{-3}$ & $1.04 \times 10^{-4}$ & 2 & $3.36 \times 10^{-4}$ & $3.32 \times 10^{-5}$ & 6 & $a>b>c$ \\
\hline $\mathrm{Na} / \mathrm{Ca}$ & $8.94 \times 10^{-3}$ & $3.82 \times 10^{-4}$ & 2 & $7.85 \times 10^{-3}$ & $1.1 \times 10^{-4}$ & 1 & $8.39 \times 10^{-3}$ & $9.57 \times 10^{-5}$ & 1 & $a=c>b$ \\
\hline $\mathrm{Cl} / \mathrm{Ca}$ & $1.48 \times 10^{-3}$ & $1.70 \times 10^{-4}$ & 3 & $1.05 \times 10^{-3}$ & $4.13 \times 10^{-5}$ & 3 & $9.27 \times 10^{-4}$ & $4.46 \times 10^{-5}$ & 2 & $a>b=c$ \\
\hline $\mathrm{S} / \mathrm{Ca}$ & $1.07 \times 10^{-3}$ & $4.49 \times 10^{-5}$ & 4 & $7.97 \times 10^{-4}$ & $1.74 \times 10^{-5}$ & 4 & $7.92 \times 10^{-4}$ & $2.07 \times 10^{-5}$ & 3 & $a>b=c$ \\
\hline $\mathrm{P} / \mathrm{Ca}$ & $8.98 \times 10^{-4}$ & $6.07 \times 10^{-5}$ & 5 & $5.52 \times 10^{-4}$ & $2.28 \times 10^{-5}$ & 6 & $5.95 \times 10^{-4}$ & $2.76 \times 10^{-5}$ & 5 & $a>b=c$ \\
\hline $\mathrm{K} / \mathrm{Ca}$ & $8.22 \times 10^{-4}$ & $5.80 \times 10^{-5}$ & 6 & $6.9 \times 10^{-4}$ & $1.59 \times 10^{-5}$ & 5 & $6.39 \times 10^{-4}$ & $1.48 \times 10^{-5}$ & 4 & $a>b=c$ \\
\hline $\mathrm{Mg} / \mathrm{Ca}$ & $2.76 \times 10^{-4}$ & $2.78 \times 10^{-5}$ & 7 & $2.02 \times 10^{-4}$ & $1.03 \times 10^{-5}$ & 7 & $2.14 \times 10^{-4}$ & $1.8 \times 0^{-5}$ & 7 & $a>b ; c=a, b$ \\
\hline
\end{tabular}

HSD, Honestly significantly different.

Table 3. Pearson correlation coefficient among seven elements : Ca ratios in weight \% within otoliths of the eel by life history stage/habitat use

\begin{tabular}{|c|c|c|c|c|c|c|c|}
\hline & $\mathrm{Sr}: \mathrm{Ca}$ & $\mathrm{K}: \mathrm{Ca}$ & $\mathrm{Cl}: \mathrm{Ca}$ & $\mathrm{P}: \mathrm{Ca}$ & $\mathrm{S}: \mathrm{Ca}$ & $\mathrm{Na}: \mathrm{Ca}$ & $\mathrm{Mg}: \mathrm{Ca}$ \\
\hline \multicolumn{8}{|c|}{ Leptocephalus } \\
\hline $\mathrm{Sr}: \mathrm{Ca}$ & 1 & & & & & & \\
\hline $\mathrm{K}: \mathrm{Ca}$ & 0.15 & 1 & & & & & \\
\hline $\mathrm{Cl}: \mathrm{Ca}$ & 0.19 & $0.62 * * *$ & 1 & & & & \\
\hline $\mathrm{P}: \mathrm{Ca}$ & $0.38 * * *$ & 0.19 & 0.05 & 1 & & & \\
\hline $\mathrm{S}: \mathrm{Ca}$ & $0.31 * *$ & $0.27 * *$ & $0.27 * *$ & 0.16 & 1 & & \\
\hline $\mathrm{Na}: \mathrm{Ca}$ & 0.03 & $0.39 * * *$ & $0.86 * * *$ & -0.07 & 0.14 & 1 & \\
\hline $\mathrm{Mg}: \mathrm{Ca}$ & 0.09 & $0.21 *$ & $0.24 *$ & -0.01 & 0.13 & $0.22 *$ & 1 \\
\hline \multicolumn{8}{|c|}{ Seawater-resident yellow eel } \\
\hline $\mathrm{Sr}: \mathrm{Ca}$ & 1 & & & & & & \\
\hline $\mathrm{K}: \mathrm{Ca}$ & $0.24 * * *$ & 1 & & & & & \\
\hline $\mathrm{Cl}: \mathrm{Ca}$ & $0.35 * * *$ & $0.14^{* *}$ & 1 & & & & \\
\hline $\mathrm{P}: \mathrm{Ca}$ & 0.03 & 0.05 & $-0.12 *$ & 1 & & & \\
\hline $\mathrm{S}: \mathrm{Ca}$ & $-0.11^{*}$ & 0.01 & 0.01 & -0.02 & 1 & & \\
\hline $\mathrm{Na}: \mathrm{Ca}$ & $0.32 * * *$ & $0.14 * *$ & $0.72 * * *$ & $-0.12 *$ & 0.03 & 1 & \\
\hline $\mathrm{Mg}: \mathrm{Ca}$ & -0.04 & 0.04 & 0.01 & 0.06 & 0.05 & -0.03 & 1 \\
\hline \multicolumn{8}{|c|}{ Freshwater-resident yellow eel } \\
\hline $\mathrm{Sr}: \mathrm{Ca}$ & 1 & & & & & & \\
\hline $\mathrm{K}: \mathrm{Ca}$ & $0.12 *$ & 1 & & & & & \\
\hline $\mathrm{Cl}: \mathrm{Ca}$ & 0.03 & 0.02 & 1 & & & & \\
\hline $\mathrm{P}: \mathrm{Ca}$ & -0.04 & 0.02 & $0.13 * *$ & 1 & & & \\
\hline $\mathrm{S}: \mathrm{Ca}$ & 0.02 & 0.09 & $0.20 * * *$ & 0.07 & 1 & & \\
\hline $\mathrm{Na}: \mathrm{Ca}$ & 0.01 & -0.04 & $0.62 * * *$ & $0.17 * *$ & $0.25 * * *$ & 1 & \\
\hline $\mathrm{Mg}: \mathrm{Ca}$ & -0.07 & 0.07 & 0.06 & 0.07 & 0.06 & 0.02 & 1 \\
\hline
\end{tabular}

$* P<0.05 ; * * P<0.01 ; * * * P<0.001$. 
Classification of the life history stage and habitat use of the eel by otolith multiple elements

Forward stepwise discriminant function analysis indicated that the other five element: $\mathrm{Ca}$ ratios (except $\mathrm{K}: \mathrm{Ca}$ and $\mathrm{Mg}: \mathrm{Ca}$ ) contributed significantly to the discrimination of the life history stage and habitat use of the eel (Table 4). The relative contribution of the element: Ca ratio to the groupings are listed in decreasing order as $\mathrm{Sr}: \mathrm{Ca}, \mathrm{Na}: \mathrm{Ca}, \mathrm{P}: \mathrm{Ca}, \mathrm{S}: \mathrm{Ca}$ and $\mathrm{Cl}$ : $\mathrm{Ca}$ (Table 4).

The plot of the first and second components of the canonical discriminant functions indicated that freshwaterresident yellow eels can be clearly separated from the leptocephali and seawater-resident yellow eels by the five selected element: $\mathrm{Ca}$ ratios in otoliths of the eel, but the latter two partially overlapped (Fig. 1). The first component of the canonical discriminant function contributed $96.3 \%$ of the variance for the grouping of the eels whereas the second component only contributed $3.7 \%$ of the variance. These two components significantly contributed in the discrimination ( $\chi^{2}$-square test, $P<0.001$ ). In the first component, the $\mathrm{Sr}: \mathrm{Ca}$ ratios contributed the greatest, followed by $\mathrm{Na}: \mathrm{Ca}$ and $\mathrm{S}: \mathrm{Ca}$. In the second component of the canonical discriminant function, the $\mathrm{Na}$ : Ca ratios were the most important, followed by $\mathrm{Cl}$ : Ca, P : Ca and S : Ca (Table 4). The cross-validated correct classification percentage in the prediction of the three different eel groups by the five element: Ca ratios was the highest in freshwater-resident yellow eels (98.0\%), followed by seawater-resident yellow eel (84.4\%), with leptocephalus being the lowest at $69.7 \%$ (Table 5 ).

\section{Discussion}

In earlier studies of the elemental composition of fish otoliths, it was believed that elemental composition reflects the elemental concentration of ambient water that the fish lives in. Thus, the Sr: Ca ratio in otoliths was widely used to study the eel migration between freshwater and marine environments (e.g. Tzeng et al. 1997, 2000, 2002, 2003a, 2003b; Tsukamoto and Arai 2001; Jessop et al. 2002, 2004; Shiao et al. 2003).
Table 4. Standardised canonical discriminant function coefficients of element : Ca ratios for discriminating the eel among different stage/habitat use as leptocephalus and freshwater- and seawaterresident yellow eels in Fig. 1

\begin{tabular}{lcc}
\hline Elemental ratio & \multicolumn{3}{c}{ Function } & 2 \\
\hline $\mathrm{Sr}: \mathrm{Ca}$ & 1.011 & -0.077 \\
$\mathrm{Cl}: \mathrm{Ca}$ & -0.047 & -0.607 \\
$\mathrm{P}: \mathrm{Ca}$ & -0.041 & 0.594 \\
$\mathrm{~S}: \mathrm{Ca}$ & 0.092 & 0.426 \\
$\mathrm{Na}: \mathrm{Ca}$ & -0.093 & 0.997 \\
Eigenvalue & 2.148 & 0.082 \\
$\%$ of variance & 96.3 & 3.7 \\
Cumulative \% & 96.3 & 100.0 \\
\hline
\end{tabular}

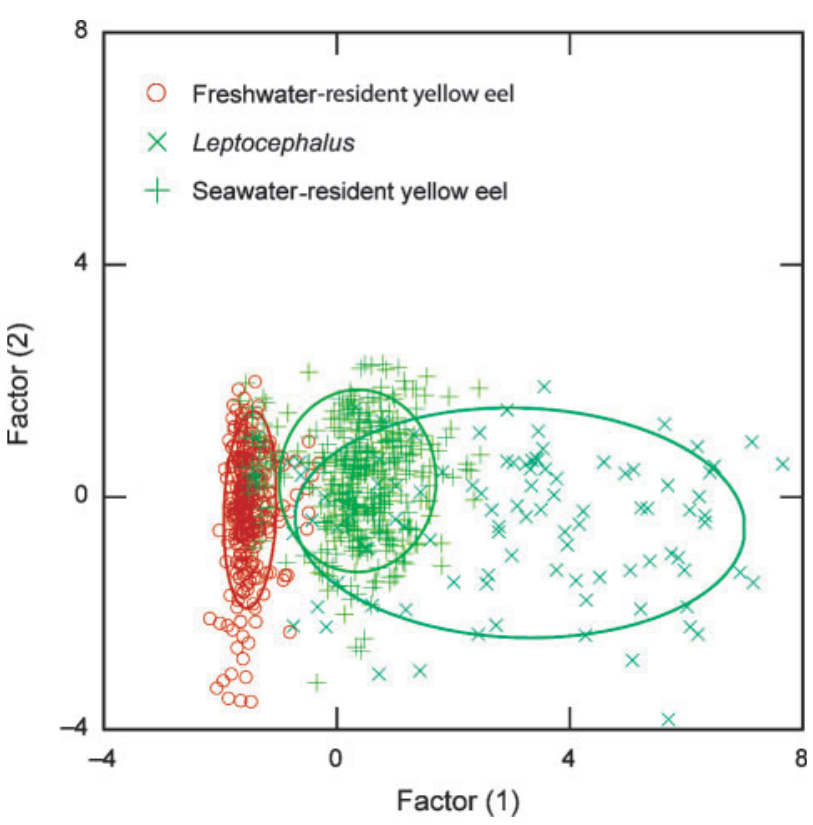

Fig. 1. Anguilla anguilla. Canonical discriminant scores plot of otolith element: Ca ratios for the European eel. The different stages assayed were those present in the adult eel otoliths, and classified by life stage and habitat use as leptocephalus, freshwater- and seawater-resident yellow eels. The elliptical circles indicate $95 \%$ confidence limit of each group.

Table 5. Cross-validated classification of the eel of different stage/habitat use by leave-one-out method using otolith elemental signature $(\mathrm{Sr}: \mathrm{Ca}, \mathrm{Cl}: \mathrm{Ca}, \mathrm{P}: \mathrm{Ca}, \mathrm{S}: \mathrm{Ca}$, and $\mathrm{Na}: \mathrm{Ca})$

Correctly classified percentages in bold

\begin{tabular}{lcccc}
\hline Stage/habitat use & $n^{\mathrm{A}}$ & \multicolumn{2}{c}{ Correct classification (\%) } \\
& & Leptocephalus & \multicolumn{2}{c}{ Yellow eel } \\
& & & Seawater-resident & Freshwater-resident \\
\hline Leptocephalus & 99 & $\mathbf{6 9 . 7}$ & 24.2 & 6.1 \\
Yellow stage eel & & & & 13.3 \\
Seawater-resident & 392 & 2.3 & $\mathbf{8 4 . 4}$ & $\mathbf{9 8 . 0}$ \\
Freshwater-resident & 304 & 0.0 & 2.0 & \\
\hline
\end{tabular}

${ }^{\mathrm{A}}$ The number of sampling spots for the measurement of elemental composition on the otoliths of the 10 yellow eels in Table 1 . 
In the present study, we explored elements other than $\mathrm{Sr}$ and found that they also changed with life stage and habitat. The Sr: Ca ratios ranked first in the leptocephalus stage, but the top rank changed to $\mathrm{Na}: \mathrm{Ca}$ in freshwater- and seawaterresident yellow stage eels. In other words, the ranking of the relative importance of the element: $\mathrm{Ca}$ ratios were different between leptocephalus and both freshwater- and seawaterresident yellow stage eels (Table 2). This demonstrated that the elemental composition in otoliths of the eel significantly changed with life stage and habitat transition. The mechanism of the change of elemental composition of the otolith with life stage is not clear in most fishes, but may relate to the elemental concentration of ambient water and osmotic pressure regulation of the diadromous eel when they change from osmoconformer in the leptocephalus stage to osmoregulation in the yellow stage eel. The body fluid of a leptocephalus is isotonic to seawater and its body tissue is known to contain extensive amounts of a gelatinous extracellular matrix composed of sulphated glycosaminoglycans (GAGs), which have an affinity for alkali elements, particularly $\mathrm{Sr}^{2+}$ (Comper and Laurent 1978; Nishizawa 1978; Hascall and Hascall 1981; Toole 1981). Sulphated glycosaminoglycans breakdown during metamorphosis from leptocephalus to glass eel may possibly reduce the absorption of $\mathrm{Sr}^{2+}$ and other elements. Thus, the $\mathrm{Sr}$ : Ca ratios in otoliths of leptocephali significantly decreased when they metamorphose into glass eels (Otake et al. 1994; Arai et al. 1997). However, the effect of ambient environment on the otolith $\mathrm{Sr}$ : Ca ratios of the eel cannot be excluded because the growth habitat shifted from high to low saline water when the eel metamorphoses from leptocephalus to glass eel and $\mathrm{Sr}$ concentration is $\sim 100$ fold higher in seawater than in fresh water (Campana 1999). On the contrary, the $\mathrm{Na}$ : $\mathrm{Ca}$ ratios in otoliths of the eel were higher in freshwater- compared with seawater-resident yellow stage eels, although $\mathrm{Na}$ concentration is higher in seawater than fresh water. This may indicate that sodium uptake is physiologically controlled by the eel. Accordingly, except with the exception of $\mathrm{Sr}$, the other elements in fish otoliths are also very important in the linking study between otolith microchemistry and the life and migratory environmental history of the fish.

This is the first paper to use multiple elements in addition to $\mathrm{Sr}$ to study the life history and migratory environment of the eel. The eight elements selected in the present study were reported to have a positive correlation in abundance between otoliths and ambient water (Goldberg 1965; Thresher 1999). With the exception of the $\mathrm{Sr}: \mathrm{Ca}$ and $\mathrm{Na}$ : $\mathrm{Ca}$ ratios, no significant difference was found among leptocephalus and both freshwater- and seawater-resident yellow eels (Table 2). This indicates that it is difficult to use a single element: Ca ratios to discriminate the eel stage and habitat use. However, the cross correlation matrix of the seven element: Ca ratios in otoliths was found to be different among stage and habitat use of the eel (Table 3). This may indicate that the elements incorporated into otoliths of the eel were conditionally selected. The canonical plot and stepwise canonical discriminant analysis also indicated that along with $\mathrm{Sr}: \mathrm{Ca}$, the other four element: $\mathrm{Ca}$ ratios $(\mathrm{Cl}: \mathrm{Ca}, \mathrm{P}: \mathrm{Ca}, \mathrm{S}: \mathrm{Ca}$ and $\mathrm{Na}: \mathrm{Ca})$ have obviously contributed to the grouping of the eels (Fig. 1). The classification success of the different stage and habitat use of the eel reached $70.7-98.0 \%$ (Table 5). This suggested that multiple-elemental information could provide additional insight into environmental life history traits of the facultative catadromous eels. A total of 31 elements have been detected in fish otoliths to date (Campana 1999). Future studies are needed to assess the use of elements that are below the detection limits of EPMA for more detailed fingerprints regarding eel otoliths.

\section{Acknowledgments}

The present study was conducted with financial support from the National Science Council (contract no. NSC 91-2313B002-291, awarded to WNT). We thank Ms Y. C. Tsai for otolith preparation, and Mr Brian M. Jessop, Dr Steven Campana and the anonymous referee for their helpful comments on an early draft of this paper.

\section{References}

Arai, T., Otake, T., and Tsukamoto, K. (1997). Drastic changes in otolith microstructure and microchemistry accompanying the onset of metamorphosis in the Japanese eel Anguilla japonica. Marine Ecology Progress Series 161, 17-22.

Bertin, L. (1956). 'Eels - A Biological Study.' (Cleaver-Hume Press: London.)

Cairns, D. K., Shiao, J. C., Iizuka, Y., Tzeng, W. N., and MacPherson, C. D. (2004). Movement patterns of American eels in an impounded watercourse, as indicated by otolith microchemistry. North American Journal of Fisheries Management 24, 452-458. doi:10.1577/M03054.1

Campana, S. E. (1999). Chemistry and composition of fish otoliths: pathways, mechanisms, and applications. Marine Ecology Progress Series 188, 263-297.

Comper, W. D., and Laurent, T. C. (1978). Physiological function of connective tissue polysaccharides. Physiological Reviews 58, 255-315.

Goldberg, E. D. (1965). Minor elements in seawater. In 'Chemical Oceanography, Vol. 1'. (Eds J. P. Railey and G. Skirrow.) pp. 181-195. (Academic Press: New York.)

Hascall, V. C., and Hascall, G. K. (1981). Proteoglycans. In 'Cell Biology of Extracellular Matrix’. (Ed. E. D. Hay.) pp. 39-63. (Plenum Press: New York.)

Jessop, B. M., Shiao, J. C., Iizuka, Y., and Tzeng, W. N. (2002). Migratory behaviour and habitat use by American eels Anguilla rostrata as revealed by otolith microchemistry. Marine Ecology Progress Series 233, 217-229.

Jessop, B. M., Shiao, J. C., Iizuka, Y., and Tzeng, W. N. (2004). Variation in the annual growth, by sex and migration history, of silver American eels Anguilla rostrata. Marine Ecology Progress Series 272, 231-244.

Kraus, R. T., and Secor, D. H. (2003). Response of otolith Sr: Ca to a manipulated environment in young American eels. American Fisheries Society Symposium 33, 79-85.

Lecomte-Finiger, R. (1992). Growth history and age at recruitment of European glass eels (Anguilla anguilla) as revealed 
by otolith microstructure. Marine Biology 114, 205-210. doi:10.1007/BF00349520

Limburg, K. E., Wickstrom, H., Svedang, H., Elfman, M., and Kristianson, P. (2003). Do stocked freshwater eel migrate? Evidence from the Baltic suggests 'Yes'. In 'Biology, Management, and Protection of Catadromous Eels'. (Ed. D. A. Dixon.) pp. 275-284. (American Fisheries Society symposium 33: Bethesda, MD.)

Nishizawa, K. (1978). Marine algae from a viewpoint of pharmaceutical studies. Japanese Journal of Phycology 26, 73-78.

Otake, T., Ishii, T., Nakahara, M., and Nakamura, R. (1994). Drastic changes in otolith strontium/calcium ratios in leptocephali and glass eels of Japanese eel Anguilla japonica. Marine Ecology Progress Series 112, 189-193.

Scott, V. D., Love, G., and Reed, S. J. B. (1995). 'Quantitative ElectronProbe Analysis.' (Ellis Horwood Limited: Hertfordshire, UK.)

Shiao, J. C., Iizuka, Y., Chang, C. W., and Tzeng, W. N. (2003). Disparities in habitat use and migratory behavior between tropical eel Anguilla marmorata and temperate eel A. japonica in four Taiwanese rivers. Marine Ecology Progress Series 261, 233-242.

Statham, P. J. (1981). X-ray microanalysis with Si (Li) detectors. Journal of Microscopy 123, 1-23.

Statham, P. J. (1982). Confidence in microanalysis; lies, damned lies or statistics. In 'Proceeding of the 17th Annual Conference of Microbeam Analytic Society'. pp. 1-7. (Microbeam Analytic Society: Washington, DC.)

Tesch, F. W. (2003). 'The Eel.' 3rd edn. (Blackwell Publishing: Oxford.)

Thresher, R. E. (1999). Elemental composition of otoliths as a stock delineator in fishes. Fisheries Research 43, 165-204. doi:10.1016/S0165-7836(99)00072-7

Toole, B. P. (1981). Glycosaminoglycans in morphogenesis. In 'Cell Biology of Extracellular Matrix'. (Ed. E. D. Hay.) pp. 259-294. (Plenum Press: New York.)

Tsukamoto, K., and Arai, T. (2001). Facultative catadromy if the eel Anguilla japonica between freshwater and seawater habitats. Marine Ecology Progress Series 220, 265-276.

Tsukamoto, K., Nakai, I., and Tesch, W. V. (1998). Do all freshwater eels migrate? Nature 396, 635-636. doi:10.1038/25264

Tzeng, W. N. (1996). Effects of salinity and ontogenetic movements on strontium:calcium ratios in the otoliths of the Japanese eel, Anguilla japonica. Journal of Experimental Marine Biology and Ecology 199 111-122. doi:10.1016/0022-0981(95)00185-9

Tzeng, W. N., and Tsai, Y. C. (1994). Changes in otolith microchemistry of the Japanese eel, Anguilla japonica, during its migration from the ocean to the rivers of Taiwan. Journal of Fish Biology 45, 671-683.

Tzeng, W. N., Severin, K. P., and Wickström, H. (1997). Use of otolith microchemistry to investigate the environmental history of European eel Anguilla anguilla. Marine Ecology Progress Series 149, 73-81.

Tzeng, W. N., Wang, C. H., Wickstrom, H., and Reizenstein, M. (2000). Occurrence of the semi-catadromous European eel Anguilla anguilla in the Baltic Sea. Marine Biology 137, 93-98. doi:10.1007/ S002270000330

Tzeng, W. N., Shiao, J. C., and Iizuka, Y. (2002). Use of otolith Sr: Ca ratios to study the riverine migratory behaviors of Japanese eel Anguilla japonica. Marine Ecology Progress Series 245, 213-221.

Tzeng, W. N., Shiao, J. C., Yamada, Y., and Oka, H. P. (2003a). Life history patterns of Japanese eel Anguilla japonica in Mikawa Bay, Japan. American Fisheries Society Symposium 33, 285-293.

Tzeng, W. N., Iizuka, Y., Shiao, J. C., Yamada, Y., and Oka, H. P. (2003b). Identification and growth rates comparison of divergent migratory contingents of Japanese eel (Anguilla japonica). Aquaculture 216, 77-86. doi:10.1016/S0044-8486(02)00053-4

Vollestad, L. A., and Jonsson, B. (1986). Life-history characteristics of the European eel Anguilla anguilla in the Imsa River, Norway. Transactions of the American Fisheries Society 115, 864-871. doi: 10.1577/1548-8659(1986)115<864:LCOTEE $>2.0 . C O ; 2$

Wang, C. H., and Tzeng, W. N. (2000). The timing of metamorphosis and growth rates of American and European eel leptocephali: A mechanism of larval segregative migration. Fisheries Research 46, 191-205. doi:10.1016/S0165-7836(00)00146-6

Zar, J. H. (1984). 'Biostatistical Analysis.' (Prentice Hall International: London.)

Manuscript received 16 July 2004; revised 22 March 2005; and accepted 6 April 2005. 
Appendix 1. Electron probe microanalyser counting times (peak and background), standards, detection limits, and analytical errors

Detection limits (wt \%) and typical analytical errors (wt \%, $1 \sigma$ ) calculated after Scott et al. (1995)

\begin{tabular}{lclcc}
\hline Element & $\begin{array}{c}\text { Counting time } \\
(\mathrm{sec})\end{array}$ & Standard & Detection limit & Typical analytical error \\
\hline $\mathrm{Na}$ & 60 & Halite (CM Taylor) & 0.029 & 0.023 \\
$\mathrm{Mg}$ & 60 & Osumilite (USNM 143967) & 0.019 & 0.022 \\
$\mathrm{P}$ & 60 & Apatite (Wilberforce) & 0.036 & 0.027 \\
$\mathrm{~S}$ & 60 & Gypsum (CM Taylor) & 0.023 & 0.017 \\
$\mathrm{Cl}$ & 46 & Halite (CM Taylor) & 0.027 & 0.015 \\
$\mathrm{~K}$ & 46 & Osumilite (USNM 143967) & 0.019 & 0.012 \\
$\mathrm{Ca}$ & 20 & Calcite (NMNH 136321) & $\mathrm{NA}$ & 0.245 \\
$\mathrm{Sr}$ & 120 & Strontianite (Smithsonian R-10065) & 0.036 & 0.019 \\
\hline
\end{tabular}

NA, Not applicable. 